\title{
The Real Architeuthis-Still Unseen, but One More Model
}

IN THE EPILOGUE TO MY ARTICLE ON THE MODELS of Architeuthis (in Curator 40/1), I mentioned an expedition to New Zealand that was to obtain pictures of the giant squid. Funded by the National Geographic Society (with additional support from the U.S. Office of Naval Research, NASA, and the New Zealand Department of Water and Atmosphere), the expedition was led by Clyde F.E. Roper, of the Department of Invertebrates at the National Museum of Natural History, probably the world's foremost authority on giant squid.

Also aboard were Malcolm Clarke, an expert on squids and sperm whales; Teddy Tucker, a Bermudian treasurediver, monster-hunter, and boat-driver; National Geographic underwater photographer Emory Kristof; Greg Stone of the New England Aquarium. James Bellingham of the Massachusetts Institute of Technology Autonomous Underwater Vehicles (AUV) Lab was aboard to direct Odyssey, a six-foot-long robotic submarine equipped with lights and a nosemounted video camera. Also included in the group was Adam Frankel of the Cornell University Ornithology Lab, who wanted to record the vocalizations of sperm whales.

When the expedition members finally assembled at Kaikoura, they had an impressive array of high-tech appliances that they were hoping would enable them to capture the elusive Architeuthis on videotape, including Odyssey and the "Ropecam," another specially-designed, computer-controlled video camera with lights and a bait-can that could be lowered to great depths dangling beneath it. They also brought the "crittercam," a video camera that can be affixed to the hide of a swimming animal, and, because of its fins, orients in the direction the animal is swimming, thereby filming what the animal sees as it swims. Be- cause Kaikoura Canyon is known to be the favored habitat of bull sperm whales, and because sperm whales eat giant squid, the idea was to film the squid as the whale chased-and maybe even caught-it. This may sound crazy, but I know that the crittercam was successfully employed with great white sharks in California waters, producing some of the most sensational footage ever taken of white sharks swimming and chasing elephant seals, and with sperm whales in the Azores. The idea was to see Architeuthis from the whale's point of view.

Alas, all these king's horses and all the king's men couldn't put this Humpty together. The New Zealand Department of the Environment wouldn't allow them to use the dart to affix the crittercam, so they were forced to rely on suction cups, which came off the whales almost immediately. None of the robot cameras sighted any squid, giant or otherwise. Toward the end of the six-week expedition, the elements turned against them too; stormy weather and rough seas made it difficult to launch the cameras. Despite the concerted efforts of this dedicated crew, it is still the case that no one has yet seen a living, healthy giant squid.

In my acknowledgments, I thanked David Heppell of the National Museum of Scotland, who provided documentation and illustrative material related to the exhibition of the U.S. National Museum's model at the 1883 International Fisheries Exhibition in London and other British models. The museum in Edinburgh has specimens of Architeuthis (one of which stranded at North Berwick in 1977) but, until recently, no model. In May 1997, the museum obtained a cast of the model in the Natural History Museum in London, and through the good offices of David Heppell, I was invited to Scotland to paint it. 


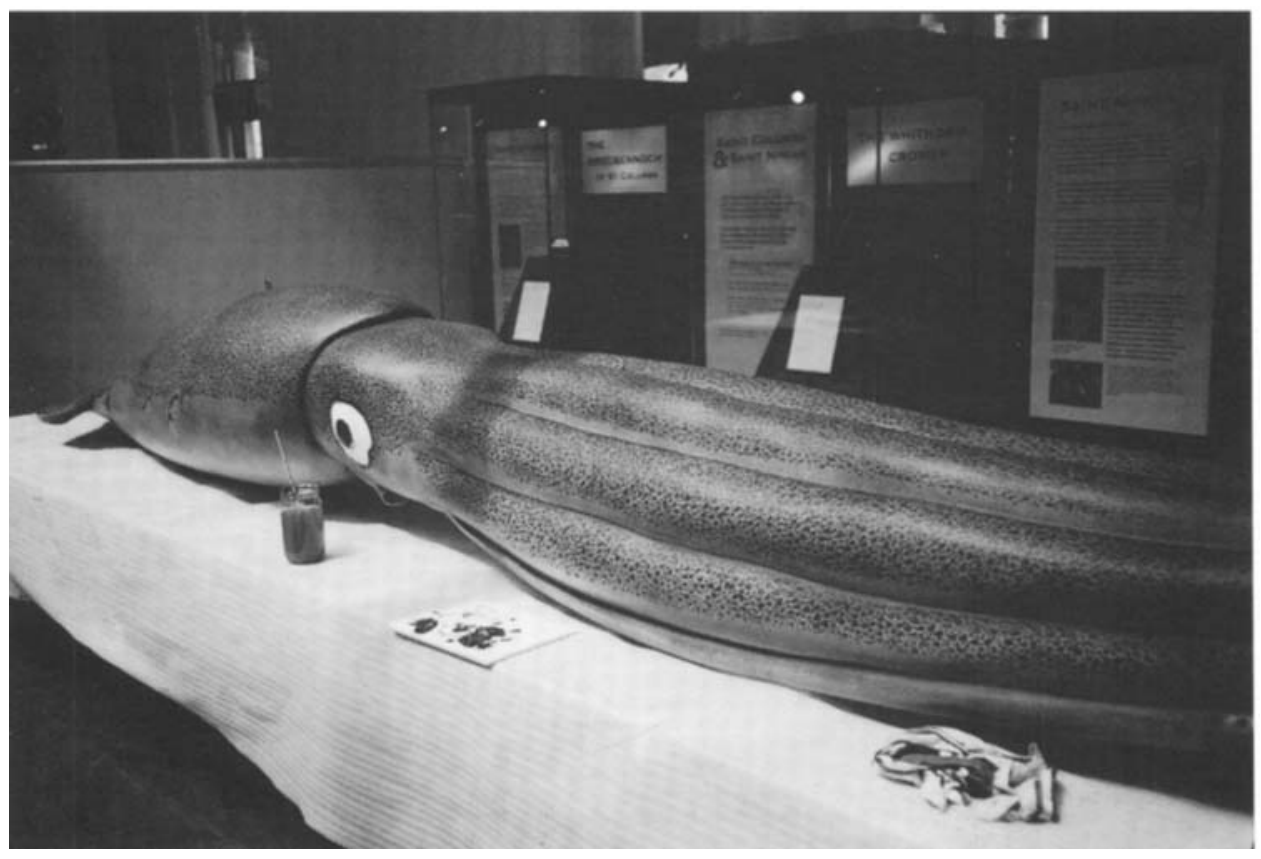

The newest model of Architeuthis, freshly painted, in the National Museum of Scotland in Edinburgh.

The model had originally been spattered with a sort of reddish-yellow paint, so I decided to delineate the chromatophores. The chromatophores are those little sacs in the skin that the animal can enlarge or reduce to change its color. Squids (and octopuses and cuttlefishes) can change color and pattern faster than any other animals in the world. They do this for camouflage, of course, but some researchers now believe that squid and cuttlefishes communicate through a language of color change. (Some squid also have photophores, cells that light up, but not $A r$ chiteuthis, a fact for which I am eternally grateful-I'm glad I didn't have to wire the thing as well as paint it.) I painted what seemed like an infinite number of little dots, half of them Venetian red and half carmine, to give the model an overall reddish appearance, and I repainted the eyes so they were no longer black with a gold-rimmed pupil. To the catalogue of Architeuthis models, you may now add another: Edinburgh. 